Papers and Proceedings of the Royal Society of Tasmania, Volume 115, 1981

(ms. received 10.9.1980)

\title{
N:W LOCALITY RECORDS AND PRELIMINARY INFORMATION ON DEMERSAL FAUNAL ASSEMBLAGES IN TASMANIAN WATERS
}

by P.R. Last and J.G.K. Harris

Tasmanian Fisheries Development Authority, Taroona, Tasmania. 7006

(with two tables and three appendices) ABSTRACT

IAST, P.R. and HARRIS, J.G.K., 1981 (30 ix): New locality records and preliminary

information on demersal fish faunal assemblages in Tasmanian waters. Pap. Proc.

R. Soc. Tasm., 115, 189-209. https://doi.org/10.26749/rstpp.115.189 ISSN 0080-4703. Tasmanian

Fisheries Develøment Authority, Taroona, Tasmania, Australia.

A survey of demersal fish resources off the Tasmanian coast in early 1979 provided guideline information on abundance and diversity of resources and the bathymetric distribution of species.

An annotated list of new Australian records includes Coelorinchus matamua McCann and McKnight, Pseudoxenomystax hirsutus (Castle), Physiculus marginatus (Günther), Pentaceros michardsoni (Smith) and Seriolella caemilea (Guichenot). New Tasmanian records include Centroscymnus crepidator (Bocage and Capello), Centrophorus uyato (Rafinesque), Etmopterus Zucifer (Jordan and Snyder), Dalatias Zicha (Bonnaterre), Raja gudgeri Whitley, Harriotta raleighana Goode and Bean, Neoscopelus macrolepidotus Johnson, Euclichthys polynemus McCulloch, Tripterophycis gilchristi Boulenger, Neocyttus rhomboidalis Gilchrist Cyttosoma boops Gilchrist, Lepidotrigla mulhalli (Macleay), Platycephalus conatus waite and McCulloch, Neophrynichthys marcidus McCulloch, Epigonus denticulatus Dieuzeide and Parika scaber (Forster).

Two skates (Raja spp) are new to science, and four other species (Raja spp., Hydrolagus sp. and Pleuroscopus sp.) have not been positively identified and may be undescribed.

Bathymetric distributions of species sampled and a subjective evaluation of community structures of Tasmanian demersal fishes are provided.

\section{INTRODUCTION}

Accurate identification and determination of species compositions are important aspects of both academic and applied studies of animal communities. The population dynamics an natural history of commercial fish species are realised as major considerations in fishery studies but the usefulness of non-commercials in defining faunal assemblages and trophic associations is often undervalued. Such information can often be obtained incidentally from more specific studies at low additional cost. The importance of knowledge relating to interspecific relationships within communities and its application to specific fisheries studies has been discussed by Cushing (1975). The southern extremity of the Australian continental shelf occurs in Tasmanian waters, rendering the area interesting zoogeographically and providing a boundary for many commercial fish species.

Collections of demersal fish from Tasmanian waters date back to voyages of the "Erebus" and "Terror" (1844). The F.I.S. "Endeavour (1909-1914) pioneered trawl fisheries research in southern Australia and while an attempt was made to identify the catch components accurately, most subsequent surveys conducted off Tasmania (Wolfe 1970; Blackburn and Fairbridge 1946; Anon. 1977, 1979a) did not provide detailed compositional data or were basically exploratory surveys of a single species (Grant 1974). On some cruises, "Academic Berg" (Parin and Bekker 1972), "Courageous" (Anon. 1975-78), "Kaiyo Maru" (Anon 1976) "Umitaka Maru" (Scott 1969, 70, 71), more extensive collecting was 
undertaken and overall species compositions were provided. Cowper and Downie (1957) provided the on $1 y$ summarised information on depth distribution of species but some species appear to have been confused with closely allied forms.

Prior to 1977 the most comprehensive recent trawling survey off the Tasmanian coast was undertaken by "Zeehaan" (Webb and Wolfe, 1977). In 1977 "Zeehaan" and a Lakes Entrance trawler, "Craigmin", were chartered to undertake exploratory trawling operations around southeastern Australia (Anon. 1977). A further grant allowed for the implementation of phase two of the survey and both vessels were re-chartered for a further exerc ise in 1978 (Anon. 1979a).

A third phase was completed in 1979. The $23 \mathrm{~m}$ stern trawler, "Zeehaan", was chartered for a three month survey off the Tasmanian west coast, and two shots were also completed on the slope off St. Helens. The basic aims were to map and explore uncharted grounds and secondly to obtain detailed information on the composition and bathymetric distribution of species on the continental shelf and slope. The latter objective is discussed in this paper and the former will be covered in detail in a separate report.

\section{METHODS}

A total of 57 trawls were made between January 5 and March 23, 1979. Some of the trawls were aborted because of hookups and for a few, incomplete species listings were obtained. Data from 40 complete samples are used in this paper. Stations and their co-ordinates and depth ranges are listed in Appendix 1.

Five trawl nets were used in the survey. These nets and their headline lengths (H. L.) are: Cosalt Three Bridle (36.6 m H.L.), Bridport Gundry 480 (24.4 m H.L.), Cosalt Aquarius (47 m H. L.), Cosalt U.R.I. (36.6 m H.L.) and Cosalt Box Traw1 (24.4 m H. L.).

Species compositions for each trawl were obtained and the results plotted in the appropriate subjectively determined depth range; 0-15 (0-27 m), 15-50 (27-91 m), 50-150 $(91-274 \mathrm{~m}), 150-250(274-457 \mathrm{~m}), 250-350(457-640 \mathrm{~m})$ or greater than 350 (640 m) fathoms (Appendix 2). Mean depths were used to categorise traw1s where the net operating depths overlapped two depth ranges.

Catch weight estimates for each species were obtained for each trawl and the relative abundances by weight for the ten major species in each depth range given (Appendix 3).

An annotated list of new records and a list of localities is presented. Explanatory notes are given where widely used scientific names for Australian species have been replaced by senior synonyms. Specimens are currently held at the T.F.D.A. Taroona Laboratory but eventually will be distributed between the Australian, Queen Victoria and Tasmanian Museums. New records have been lodged at the Tasmanian Museum; registration numbers (Tas. Mus. No.) are provided.

\section{RESULTS AND DISCUSSION}

Taxonomic Notes

\section{SQUALIDAE}

Deania calcea (Lowe, 1839)

$522,24,28,33,35,37,38,39,40$.

This species is listed from Tasmania (Cowper and Downie 1957; Munro 1956) as a junior synonym D. kaikourae (Whitley) (Garrick, 1960a) 
Centrophoms uyato (Rafinesque, 1810)

$\mathrm{S} 24,29$. (Tas. Mus. No. D 1610).

Superficially resembles the other Centrophoms species and was only recently recorded from Australia (Gorman and Graham 1976). The specimens above represent the first record, of the species for Tasmania.

Centroscymmis crepidator (Bocage and Capel10, 1864).

$\mathrm{S} 37$, 40. (Tas. Mus. No. D 1611)

Recorded from Australia by Gorman and Graham (1978); two specimens above are the first for Tasmania.

Etmoptems Zucifer (Jordan and Snyder, 1902).

S25, 27, 29, 32, 36, 39, 40. (Tas. Mus. No. D 1612).

New record for Tasmanian waters.

Squalus blainvizzei Risso, 1826).

$S 17,23,25,27,29,30,31,32,36$. (Tas. Mus. No. D 1613).

Garrick (1960b), al though unable to procure specimens from Australian waters, listed S. tasmaniensis Rivero from Tasmania as a junior synonym of this species. Material referred to by Gorman and Graham (1976) and herein confirms the occurrence of this species in Australian waters.

Squalus acanthias (Linnaeus, 1758).

S1.

A cosmopolitan species, common1y found in Tasmanian waters but known by the junior synonym S. kirki Phillipps.

\section{DALATI IDAE}

Dalatias licha (Bonnaterre, 1788).

S31, 33, 34, 36, 38, 40. (Tas. Mus. No. D 1614).

First record for Tasmania; assumed to be conspecific with $D$. phizlippsi (Whitley) which has been recorded from southern Australia (Munro 1956).

\section{RAJIDAE}

Raja sp. 1

S7. (Tas. Mus. No. D 1615).

The taxonomy of Australian rajids is confused owing to extreme intraspecific, ontogenetic and sexual variation for fishes that are very similar interspecifically. This species is similar to $R$. Zempriem; although herein discriminated it may eventually be found conspecific with that species.

Raja sp 2

S19, 21, 22, 23, 24, 25, 29, 31, 35, 36, 37, 39. (Tas. Mus. No. D 1616).

Appears to be a valid undescribed species.

Raja sp. 3

S19, 21, 22, 23, 24, 28, 29, 30, 33, 34, 36, 37. (Tas. Mus. No. D 1617).

Appears to be a valid undescribed species.

Raja gudgeri Whitley, 1940 .

$\mathrm{S} 29,36,37,39$. (Tas. Mus. No. D 1618)

Holotype collected from Great Australian Bight. New Tasmanian record.

Raja sp. 4

S19, 35, 37. (Tas. Mus. No. D 1619)

Similar to and possibly juvenile form of $R$. gudgeri. 
192

\section{CHIMAERLDAE}

Hydro Zagus sp. 1

S19, 20, 21, 22, 23, 24, 25, 26, 28, 30, 31, 32, 35, 36, 37, 39, 40. (Tas. Mus. No. D 1520).

Allied to $H$. Zemures Whitley but differs in some features; may prove to be conspecific with that species.

\section{RHINOCHIMAERIDAE}

Harriotta raleighana Goode and Bean, 1894

S33, 34, 37, 39. (Tas. Mus. No. D 1621).

New record for Tasmanian waters.

CONGRIDAE

Pseudoxenorystax hirsutus Castle, 1960

S35, 38. (Tas. Mus. No. D 1622).

Previously known on $1 y$ from New Zealand, the above specimens are the first recorded from Australian waters.

\section{ARGENTINIDAE}

Argentina australiae Cohen, 1958

S11, 12 .

This species was first described as a subspecies of $A$. elongata Hutton and is now recognised as a valid species (Cohen 1969). Previous Tasmanian records of $A$. ezongata are most likely attributable to $A$. australiae.

\section{NEOSCOPELIDAE}

NeoscopeZus macrolepidotus Johnson, 1863

S38. (Tas. Mus. No. D 1623).

New record for Tasmanian waters.

\section{MORIDAE}

Physiculus marginatus (Gunther, 1878)

S23, 24, 32, 36, 37. (Tas. Mus. No. D 1624).

Previously known only from Patagonian waters (Norman 1937); specimens above represent first Australian records for the species.

Euclichthys polynemus McCulloch, 1926

$\mathrm{S} 20,22,24,26,35$. (Tas. Mus. No. D 1625).

A new record for Tasmanian waters. This species is not really a morid, but its true taxonomic position has not been ascertained (Svetovidov 1969).

Tripterophycis gizchristi Boulenger, 1904

S26, 32, 35, 37. (Tas. Mus. No. D 1626).

A new record for Tasmanian waters.

\section{MACROURIDAE}

CoeZorinchus matamua McCann and McKnight, 1980

S21, 27, 30, 36, 38, 39, 40. (Tas. Mus. No. D 1627).

This species was recently described from New Zealand (McCann and McKnight 1980) and is hereby first recorded for Australia. 
Ventrifossa nigromaculatus (McCulloch, 1907)

$\mathrm{S} 22,26,28,35,37,40$.

Some specimens were collected by "Courageous" (1976) in Storm Bay. This record is now substantiated.

\section{TRACHICHTHYIDAE}

Hoplostethus intermedius (Hector, 1875)

S31, 33, 36 .

Also collected by "Courageous" (1976) from Tasmanian waters but not recorded as new.

\section{BERYCIDAE}

Beryx spZendens Lowe, 1833

$521,23,30,32,33,34,35,36$

Collected in Storm Bay by "Courageous". Appears to be our most common deep water berycid.

ZEIDAE

Cyttus traversi (Hutton, 1872)

$S 20,21,22,23,24,25,26,27,28,29,31,32,33,34,35,36,37,39,40$.

The only Tasmanian record of this common commercial species is in catch data from a previous "Zeehaan" cruise (Anon. 1979a).

\section{OREOSOMATIDAE}

Neocyttus rhomboidalis Gilchrist, 1906

S23, 25, 27, 29, 31, 32, 33, 34, 35, 36, 37, 38, 39, 40. (Tas. Mus. No. D 1628).

The species has been recorded from southeastern Australia but not specifically from the Tasmanian shelf where it is extremely abundant.

Cyt tosoma boops Gilchrist, 1904

S37, 39, 40. (Tas. Mus. No. D 1629).

New record for Tasmanian waters.

\section{MACRORHAMPHOS IDAE}

Centriscops obliquus Waite, 1911

S20, 21, 22, 23, 24, 25, 26, 27, 28, 29, 30,31, 32, 33, 34, 35, 36, 37, 39.

Recognised by some authors (McCulloch 1929; Munro 1958) as a junior synonym of C. humerosus (Richardson). However, the true identity of Richardson's species remains unknown.

Macrorhamphosus scolopax (Linnaeus, 1758)

S11.

The specific status of $M$. scolopax and $M$ elevatus Waite is subject to differing schools of thought and requires further taxonomic attention (Scott 1961). The authors are in agreement with Mohr (1937) so only a single cosmopolitan species is listed.

\section{TRIGLIDAE}

Lepidotrigla muZhalzi (Macleay, 1884)

$\mathrm{S} 2,3,5,6,7,8$. (Tas. Mus. No. D 1630).

New record for Tasmania. This species and $L$. modesta waite appear in the past to have been confused with Paratrigza vanessa (Richardson). 


\section{PLATY CEPHALIDAE}

Platycephalus conatus Waite and McCulloch, 1915

S8, 10, 11, 12, 13, 15, 16, 17, 19. (Tas. Mus. No. D 1631).

This species has been previously recorded as $P$. speculator klunzinger. $P$. specuZator most closely resembles $P$. michardsoni Castelnau, but, unlike both other species, lacks a swim bladder.

\section{PSYCHROLUTIDAE}

Neophrynichthys marcidus McCulloch, 1926

$\mathrm{S} 36,37,39$. (Tas. Mus. No. D 1632).

Exact locality of the type unknown (Nelson 1977) but samples collected during recent trawling by the "Courageous" have extended its distribution around southern Australia. The above specimens constitute first records for Tasmania.

\section{APOGONIDAE}

Epigonus denticulatus Dieuzeide, 1950

S23, 24, 26, 28, 31, 35, 36, 37.

(Tas. Mus, No. D 1633).

A cosmopolitan species (Mayer 1974) not previously recorded from Tasmanian waters.

\section{PENTACEROTIDAE}

Pentaceros michardsoni (Smith, 1849)

S32. (Tas. Mus. No. D 1634).

A specimen collected from $550 \mathrm{~m}$ (300 ftms) represents the first Australian record. The species is apparently rare in New Zealand and South Africa but is caught in commercial quantities in the North Pacific (James 1978) with exceptional catches reported from Hawaiian waters (Anon. 1979b).

Pleuroscopus sp.

S24, 28, 29, 35. (Tas. Mus. No. D 1636).

A South African species $P$. pseudodorsalis Barnard was recently collected (Anon $1979 \mathrm{c}$ ) in the Western Great Australian Bight. These are the only records of the genus from Australian waters. Tasmanian specimens differ morphometrically and meristically from the holotype but more specimens need to be examined before their relationship can be determined.

\section{CENTROLOPHIDAE}

Semizezza Caemulea Guichenot, 1848

S24, 28, 29, 32, 33, 35, 36, 37. (Tas. Mus. No. D 1637).

First Australian record of adults. Juveniles may have been recorded as a separate species. Known from Patagonia (Norman 1937), and New Zealand (Paul 1978).

\section{MONACANTHIDAE}

Parika scaber (Forster, 1801)

$\mathrm{S} 2,5,6$, (Tas. Mus. No. D 1638).

Originaliy figured by Scott (1962) incorrectly as Novodon australis (Donovan). Although $P$. scaber has been recorded previously as Navodon setosus from deep water in Bass Strait (Scott 1960; Waite and McCulloch 1915; Whitley 1931), it was omitted from the Tasmanian records (Hutchins 1977; Last 1975) because of confusion with Meuschenia austrazis.

\section{FAUNAL ASSEMBLAGES}

Methods of examining species groupings in some marine studies have been outlined by Sheard (1965). Statistical analyses can only be used with data containing adequate numbers of replicates, hence many (Fish 1925; Sheard 1949; Baker 1954 and Glover 1957) have not attempted to give objective expression to their observations. 
Fage $r$ and Longhurst (1968) used recurrent group analysis (Fager 1957, 1963) to examine demersal fish assemblages in the tropical eastern Atlantic. They found that where practicable the method can be a useful tool in resource evaluation. However, they highlighted the importance of good subjective techniques when more refined methods cannot be applied to the data. Owing to the low number of sampling replicates, the data obtained in this survey were not analysed statistically.

Subjective analysis indicates the presence of two major distributional zones exhibiting only minor faunal overlap; these are defined by the continental shelf (shallower than $275 \mathrm{~m}-150$ fathoms) and slope (deeper than $275 \mathrm{~m}$ ). Interpretation of structuring from a direct comparison of species numbers in the similarity matrix (Table 1) was occluded by the presence of twelve eurybathic species (Cephatoscyltium laticeps, Galeus boaronani, Galeorhinus australis, Squalus megalops, Squalus blainvillei, Chlorophthaimus nigripinnis, Genypterus blacodes, Macruronus novaezelandiae, Lepidorhynehus denticulatus, Helicolemus papilzosus, Rexea solandri, and Seriolella punctata) that occurred both on the shelf and below $460 \mathrm{~m}$ (250 ftms). Removal of these species from the matrix (Table 2) provided a better picture of the infra-structure within each zone.

TABLE 1

PERCENTAGE SIMILARITY MATRIX GIVING SPECIES NUMBERS ( $\mathrm{n}$ ) AND OVERLAPPING OCCURRENCE AT EACH DEPTH RANGE

\begin{tabular}{|c|c|c|c|c|c|c|c|}
\hline $\begin{array}{l}\text { Depth range } \\
\text { (fathoms) [m] }\end{array}$ & $0-15[27]$ & $15-50[91]$ & $50-150[275]$ & $150-250[457]$ & $250-350[640]$ & $>350[640]$ & $\mathrm{n}$ \\
\hline $0-15[27]$ & 100 & 72 & 33 & 6 & 11 & 0 & 18 \\
\hline $15-50[91]$ & 20 & 100 & 38 & 9 & 11 & 5 & 65 \\
\hline $50-150[275]$ & 13 & 53 & 100 & 28 & 28 & 11 & 47 \\
\hline $150-250[457]$ & 4 & 24 & 52 & 100 & 84 & 52 & 25 \\
\hline $250-350[640]$ & 4 & 16 & 29 & 47 & 100 & 69 & 45 \\
\hline$>350[640]$ & 0 & 8 & 14 & 36 & 86 & 100 & 36 \\
\hline
\end{tabular}

TABLE 2

PERCENTAGE SIMILARITY MATRIX AS IN TABLE 1 BUT WITH THE TWELVE EURYBATHIC SPECIES REMOVED

\begin{tabular}{|c|c|c|c|c|c|c|c|c|}
\hline & $\begin{array}{l}\text { Depth range } \\
\text { (metres) }\end{array}$ & $0-27$ & $27-91$ & $91-275$ & $275-457$ & $457-640$ & $>690$ & $n$ \\
\hline L & $0-27$ & 100 & 69 & 25 & 0 & 0 & 0 & 16 \\
\hline 7 & $27-91$ & 19 & 100 & 31 & 2 & 0 & 0 & 58 \\
\hline 贾 & $91-275$ & 11 & 51 & 100 & 11 & 3 & 0 & 35 \\
\hline in & $275-457$ & 0 & 6 & 25 & 100 & 75 & 56 & 16 \\
\hline$F$ & $457-640$ & 0 & 0 & 3 & 36 & 100 & 84 & 33 \\
\hline$\frac{7}{12}$ & $>640$ & 0 & 0 & 0 & 29 & 84 & 100 & 31 \\
\hline
\end{tabular}

Three faulal assemblages appear to be evident on the shelf and upper slope. Although only one sample was taken in less than $27.5 \mathrm{~m}$ (15 ftms), elements of a shallow water inshore fauna are apparent. These observations are substantiated by unpublished studies being currently undertaken in the bays and estuaries around Tasmania and in essence are similar to the findings of walker (1979). 
The second, an inner shelf assemblage $(27.5 \mathrm{~m}-90 \mathrm{~m})$, is well defined, consisting of a fauna which is more diverse than and differs in composition from the outer shelf and slope edge $(90-275 \mathrm{~m})$. Although these faunas are rather different it is not suggested that the $90 \mathrm{~m}$ contour is their "limiting line". Discrete boundaries in faunal distributions are mythical features that are more idealistic than realistic. It is likely that these communities are more complex than indicated in this study and may be further subdivided. Examples of those species most indicative of the inner shelf are Pristiophorus nudipimis, Lepidotrigla muthali $i$ and Thamnoconus degini while Raja nitida, Hydrolagus ogilbyi, Coelorinchus autralis and Notopogo lizlei are typical outer shelf species.

The trawled area of slope appears to possess at least two assemblages. An upper slope fauna is well defined with many species occurring down to $730 \mathrm{~m}(=400 \mathrm{fthms})$. The best indicators of this community are: Oxynotus bmuiensis, Raja sp. 3, Euczichthys polynemus, Beryx splendens and Zenopsis nebulosus. Suggestions of a fifth assemblage appear with the fringe occurrence, at depths above $550 \mathrm{~m}$, of some species recorded by previous authors (Cowper and Downie 1957; Garrick 1960) as having extended distributions down the slope and probably form part of a mid-slope fauna. Best indicators of this assemblage are: Mora dannevigi, Daenia calcea, Scymnodon plunketi, Centroscymmus crepidater and DaZatias Zicha and possibly Cyttosoma boops, Neophrynichthys mareidus and coezorinchus innotabilis

Problems in viewing all communities as highly stable co-adapted groups in equilibrium have been discussed by Mills (1969). Depth occurrence of some species are further complicated by variations in the physical environment. Work by Fager and Longhurst (1968) support comments by Smith (1950) on the heterogeneity of deep water fish faunas but the importance of temperature in the bathymetric distribution of species is stressed. Newe 11 (1974), in the study of southern Tasmanian water masses, found that waters below the shelf edge were of one type but on the shelf they became complex and exhibited marked seasonal changes. Thermal stratification and shifts in the thermocline in summer may not affect all species, but the distribution of stenothermal species may be slightly deeper at this time of year.

Clearly many questions need answering before community structure in this region is fully understood. Primarily there is a need to establish a better picture of depth distributions of each species and simultaneously examine coexistence patterns to see if the shelf assemblages can be further sub-divided. Bennett and Pope (1953) have shown the presence of distinct faunal provinces on southern Australian shores and there appears to be a similar structuring of reef fish populations (Last 1979). Fager and Longhurst (1963) have shown that inner shelf faunas can sometimes be split into a number of subcommunities. Complex shelf areas such as Bass Strait may possess complex community structures, as indicated by recent Tasmanian studies (unpublished data).

It is well established that the number of fish species is higher in the more ecologically diverse littoral zone than in deeper offshore waters (Smith 1950). This hypothesis is supported by results from this survey. From a total of 129 species, numbers on the shelf and slope totalled 90 and 54 respectively, sample numbers in each zone were almost equal.

Abundance data for each depth range (Appendix 3) suggested a reversal of the above trends. High total catch rates (weight of fish caught/hour) for each of the three slope depth ranges were experienced; similarly, commercial catch rates were higher for the slope samples. However, relative abundance data only provide an approximation to the real situation, as many variables (i.e. tide, net type and time of day) were not constant throughout the sampling. The dangers of using trawl data as an absolute measure of demersal fish abundances are evident from the work of Fenaughty and 0'Sul1ivan (1978).

Faunal 1ists of littoral fishes from south-eastern Australia (Winstanley 1979) and New Zealand (Webb 1972) are essentially similar in composition to the fauna of Tasmanian waters. Several species appear to be endemic to the southern Australian region (i.e. some rajid, urolophid, platycephalid, pleuronectid, bothid and monacanthid species 
although some are represented by congeners in other seas.

Briggs (1974) regarded the degree of endemism of Tasmanian fishes as $1 y$ ing between 10 and 30 percent, with the Clinidae, Rajidae, Ostraciontidae and Bovichthyidae as major groups. Apart from some rajid species, all members of these families are confined to the shelf, with the possible exception of Raja sp. 1, none of the shelf species taken in this survey is endemic to Tasmanian waters. Endemism appears to be greatest in the intertidal and shallow subtidal zones (unpublished data), but the degree is certainly much less than 10 percent.

The slope fauna is widely distributed with several species either antitropically (i.e Squalus blainvizzei, Centrophoms uyato and Pentaceros richardsoni) or circumglobally (i.e. Etmoptems zucifer, Coelorinchus fasciatus) distributed and some may be cosmopolitan. Many species, at this stage, are only "superficial" endemics and increased knowledge of these fishes will result in a reduction in endemism (Smith 1950).

Some features of community compositions require brief discussion. Eight families of elasmobranchs, most of which are commercially important, comprise over 30 percent of the total complement of trawl species compared with about 5 percent in shallow inshore waters. The most diverse of these were the squalids, represented by ten species, which were most numerous on the continental slope. Although most species are widely distributed outside Australian waters, in contrast, all members of two rajiform families,

Rajidae (10 species) and Urolophidae (4 species) are endemic to the Australian/New Zealand region. Urolophids, being both viviparous and confined to the shelf, experience only localised dispersal. The more homogeneous physical environment of deep water skates is less restricting, geographically, than for shelf species. However behavioural (in low activity benthics) and reproductive (production of demersal eggs) characteristics are possibly major factors in causing the marked endemism exhibited by the group in different marine provinces throughout the world.

The macrourids are the most diverse family of demersal teleosts in this area. Such findings are in accordance with Pearcy and Ambler (1974), who rank the group as the dominant fishes on the slopes and adjoining abyssal plains of the world. In addition, many species still possibly remain unrecorded in Australian waters (McCann and Mcknight 1980). The group is very important commercially (Pechenik and Troyanovskii 1970) and although Tasmanian species are not exploited, a close relative, the merlucciid, Macmironus novaezelandiae is potentially Tasmania's most important trawl species. Speciose teleost groups of commercial interest include the morids, triglids, uranoscopids and zeids, while some other less diverse families, such as the ophidiids, platycephalids, cheilodactylids, gempylids, centrolophids and pleuronectids, contain important commercial species.

\section{ACKNOWLEDGEMENTS}

We thank observers from D.P.I. and T.F.D.A. and the crew of the "Zeehaan" for the collection of specimens and trawl data. Also to Dr. D. Cohen, Dr. T. Dix and Dr. J. Paxton for their comments. Mrs. F. Reynolds typed the manuscript.

\section{REFERENCES}

Anonymous, 1975-1978: Summary of "Courageous" cruises 3-37. C.S.I.R.O. Div. Fish. Oceanog. Mim. Rep.

Anonymous, 1976: "Kaiyo Maru" Investigation Cruise Report. Japan Fisheries Agenoy. Mim. Rep.

Anonymous, 1977 : South-east Australian deep water trawl survey. Dep. Primary Industry, Fisheries Division. Fisheries Rep. 15: $52 \mathrm{pp}$.

Anonymous, 1979a. South-east Australia deepwater trawl survey. Phase 2. Dep. Primary Industry, Fisheries Division. Fisheries Rep. 16:40 pp.

Anonymous, 1979b: Resource assessment and development investigations. South-west Fisheries Center. Mim. Rep. 
Anonymous, 1979c: A summary of "Courageous" cruises 046, 047K. C.I.S.R.O. Div. Fish. Oceanog. Mim. Rep.

Baker, A. Dec., 1954: The circumpolar continuity of Antarctic plankton species. Dise. Rep. 27: 201-218.

Bennett, I, and Pope, E. C., 1953: Intertidal zonation of the exposed rocky shores of Victoria, together with a rearrangement of the biogeographical provinces of temperate Australian shores. Aust. J. Mar. Freshwater Res. 4(1): 105-160.

Blackburn, M. and Fairbridge, W.S., 1946: Report on the Danish-seining trials by the M.V. "Liawenee", in southern Tasmanian waters. J. Coun. Sci. and ind. Res. Aust. 19 (4): $404-413$.

Briggs, J.C., 1974: MARINE ZOOGEOGRAFHY. MCGraw-Hill, New York.

Cohen, D.M., 1969: Additions to a revision of Argentinine fishes. Fish. Bull. 68: $13-36$.

Cowper, T.R., and Downie, R.J., 1957: A line fishing survey of the fishes of the southeastern Australian continental slope. C.S.I.R.O. Div. Fish. Oceanog. Rep. 6: 23 pp. Cushing, D.H., 1975: MARINE ECOLOGY AND FISHERIES. Cambridge Uni. Press, London. Fager, E.W., 1957: Determination and analysis of recurrent groups. Eeo Zogy 38 (4): 586-595.

Eager, E.W., 1963: Communities of organisms. In Hill, M.N. (Ed.): THE SEA. New York Interscience Publishers. 415-437.

and Longhurst, A.R., (1968): Recurrent group analysis of species assemblages of demersal fish in the Gulf of Guinea. J. Fish. Res. Bd. Can. 25 (7): 1405-1421.

Fenaughty, J.N. and O'Sullivan, K., 1978: Southland trawling prospects for the bottom trawl industry. Fisheries Tech. Rep. 154: 151 pp M.A.F. Information Services, Wellington.

Fish, C.J., 1925: Seasonal distribution of the plankton of the Woods Hole region. BuZt. U.S. Bur. Fish. 41: 91-179.

Follett, W.I. and Dempster, L.J., 1963: Relationships of the percoid fish Pentaceros richardsoni smith, with description of a specimen from the coast of California. Proc. Cal. Acad. Sci. 32 (10): 315-338.

Garrick, J.A.F., 1960a: Studies on New Zealand elasmobranchii Part XI. Squalids of the genera Deania, Etmoptems, Oxynotus and Dalatias in New Zealand waters. Trans. R. Soc. N.Z. 88 (3): $489-517$.

, 1960b: Studies on New Zealand elasmobranchii. Part XII. The species of Squalus from New Zealand and Australia; a general account and key to the New Zealand Squaloidea. Trans. R. Soc. N.Z. 88 (3): 519-557.

Glover, R.S., 1957: An ecological survey of the drift net herring fishery off the northeast coast of Scotland. Part II. The planktonic environment of the herring. BuZz. Mar. Ecol. 5: 1-43.

Gorman, T.B. and Graham, K.J., 1976: Cruise Report of F.R.V. "Kapala" - No. 34 for cruises 76-15 and 76-16. N.S.W. State Fisheries, Mim. Rep.

1978: Cruise report of F.R.V. "Kapala" No. 46 for cruises 77-23 and 77-24. N.S.W. State Fisheries Mim. Rep.

Grant, J.F., 1974: Observations during a cuttlefish survey of Craig Mostyn \& Co. Pty. Lta., 1973. Fisheries Division, Tasmanian Department of Agriculture. Mim. Rep. $13 \mathrm{pp}$.

Hutchins, J.B., 1977: Descriptions of three new genera and eight new species of monacanthid fishes from Australia. Ree. West. Aust. Mus. 5 (1): 3-58.

Iwamoto, T., 1978: Eastern Pacific macrourids of the genus Ceolorinchus Giorna (Pisces: Gadiformes) with descriptions of a new species from Chile. Proc. Calif. Acad. Sci. $41(12): 307-337$.

James, G., 1978: Fishes of the E.E.z.: N.z. Boarfishes, Pigfishes, and Bellows fishes. Catch $1786(8): 12-13$.

Last, P.R., 1975: Aspects of the taxonomy and ecology of Tasmanian Leatherjackets (F. Monacanthidae, Pisces). Univ. Tasm. Unpulb. Thesis. $147 \mathrm{pp}$.

, 1979: First records of the one spot puller (Chromis hypsizepis) and the spotted stingaree (Urolophus gigas) from Tasmanian waters with an annotated list of fishes recorded from Kent Islands, Bass Strait. Tas. Nat. 59: 5-12.

Lord, C.E. and Scott, H.H., 1924: A SYNOPSIS OF THE VERTEBRAME ANIMALS OF TASMANIA. oldham, Beddome and Meredith, Hobart. 
P.R. Last and J.G.K. Harris

McCann, C. and McKnight, D.G., 1980: The marine fauna of New Zealand, macrourid fishes (Pisces: Gadida). N.Z. Oceanog. Inst. Mem. 61: 1-91.

Mcculloch, A.R., 1929: A checklist of the fishes recorded from Australia. Aust. Mus. Mem. 5: 1-534.

Mayer, G.F., 1974: A revision of the cardinal fish genus Epigonus (Perciformes, Apogonidae), with descriptions of two new species.Bul2. Mus. Comp. 2002. 146 (3): 147-203.

Mills, E.I., 1969: The community concept in marine zoology, with comments on continua and instability in some marine communities: a review. J. Fish. Res. Bd. Can. 26: 1415-1428.

Mohr, E., 1937: Revision of the Centriscidae (Acanthopterygi-Centrisciformes). Dana Rep. 13: 1-69.

Munro, I.S.R., 1956-1961: Handbook of Australian Fishes. Fisheries Newsletter. 15-20: $172 \mathrm{pp}$.

Nelson, J.S., 1977: Fishes of the southern hemisphere genus Neophrynichthys (Scorpaeniformes: Cottoidei), with descriptions of two new species from New Zealand and Macquarie Island. J. Roy. Soc. N.Z. 7 (4): 485-51l.

Newell, B.S., 1974: Distribution of oceanic water types off southeastern Tasmania, 1973. C.S.I.R.O. Div. Fish Oceanog. Rep. 59: $15 \mathrm{pp}$.

Norman, J.R., 1937: Coast Fishes Part II. The Patagonian Region. Disc. Rep. 16: $1-150$.

Parin, N.V. and Bekker, V.E., 1972: Classification and distribution data of some trichiurid fishes (Pisces, Trichiuroidae, Scombrolabracidae, Gempylidae, Trichiuridae). U.S.S.R. Acad. of Science - Works of the Institute of Oceanic Studies 93: 1-27. (In Russian).

Paul, L., 1978: Fish species of the E.E.z. First of a series. Catch 78 5 (2): 12-13. Pearcy, W.G. and Ambler, J.W., 1974: Food habits of deep-sea macrourid fishes off the Oregon coast. Deep Sea Res. 21 (9): 745-759.

Pechenik, L.N. and Troyanovskii, F.M., 1970: TRAWLING RESOURCES OF THE NORTH ATLANTIC CONTINENTAL SLOPE. Israel Program for Scientific Translations $65 \mathrm{pp}$.

Scott, E.O.G., 1960: observations on some Tasmanian fishes, Part IX. Pap. Proc. R. Soc. Tasm. 94: 87-100.

1961: Observations on some Tasmanian fishes. Part x. Pap. Proc. R. Soc. Tasm. 95: 49-65.

1969: Notes on some fishes collected in Tasmanian waters by the "Umitaka Maru" in January 1968. Part I. Sharks and Rays. Tas. Fish. Res. 3 (2): 11-16. - 1970: Notes on some fishes collected in Tasmanian waters by the "Umitaka Maru" in January 1968. Part 2, Teleosts. Tas. Fish. Res. 4 (1): 13-18. , 1971: Notes on some fishes collected in Tasmanian waters by the "Umitaka Maru" in January 1968. Part 3. Teleosts. Tas. Fish. Res. 5 (1): 14-26

Scott, T.D., 1962: THE MARINE AND FRESHWATER FISHES OF SOUTH AUSTRALIA: Govt. Printer, Adelaide.

Sheard, K., 1949: Plankton characteristics at Cronulla, N.S.W., 1943-1946. C.I.S.R.O. Aust. Bulz. 246: 1-23.

1965: Species groups in the zooplankton of eastern Australian slope waters (1938-41). Aust. J. Mar. Freshwater Res. 16: 219-254.

Smith, J.I.B., 1950: THE SEA FISHES OF SOUTHERN AFRICA. Central News Agency Ltd., South Africa.

Svetovidov, A.N., 1969: On systematic position of Euclichthys (Pisces, Gadiformes). Zool. 2h. 46: 1824-1831. (In Russian).

Waite, E.R. and McCulloch, A.R., 1915: The fishes of the South Australian Government trawling cruise, 1914. Trans. R. Soc. S. Aust. 39: 455-476.

Walker, M., 1979: An inventory of the marine resources of the Bunbury marine area and Geographe Bay. W.A. Dep. Fish. Wizdl. Rep. 37: $46 \mathrm{pp}$.

Webb, B.F., 1972: Bottom trawling in Cook Strait and western Taranaki Bight. N.Z. Mar. Dep. Fish. Tech. Rep. 77: 1-20.

and wolfe, D.C., 1977: Trawl data from a survey around Tasmania by the F.V. "Zeehan." July 1975 to June 1976. Tas. Fish. Res. 21: 15-23.

Whitley, G.P., 1931: Studies in ichthyology 4. Rec. Aust. Mus. 18: 96-133. 
Winstanley, R.H., 1979: Results of otter trawling by the F.V. "Battle Axe" in central Victorian coastal waters. Vic. Fish. Wizdz. Pap. 18: 1-17.

Wolfe, D.C., 1970: Report on Urania" Cruise in Tasmanian waters. Fishemies Division, Tasinonion Department of Agriculture. Mim. Rep. 5 pp.

\section{APPENDIX 1}

TRAWL STATIONS

\begin{tabular}{|c|c|c|c|c|c|c|c|c|}
\hline $\begin{array}{l}\text { DEPTH } \\
\text { CODE }\end{array}$ & $\begin{array}{r}\text { CRUISE } \\
\mathrm{CO}\end{array}$ & $\begin{array}{l}\text { /STATION } \\
\text { ODE }\end{array}$ & Lat. & START & Long. & Lat. & FINISH & $\begin{array}{l}\text { DEPTH RANGE } \\
\text { (metres) }\end{array}$ \\
\hline 1 & $\mathrm{CO} 7$ & -10 & $42^{\circ} 00^{\prime} \mathrm{S}$ & & $145^{\circ} 14^{\prime} \mathrm{E}$ & $42^{\circ} 04^{\prime} \mathrm{S}$ & $145^{\circ} 13^{\prime} \mathrm{E}$ & 22 \\
\hline 2 & $\mathrm{C} 10$ & -01 & $40^{\circ} 20^{\prime} \mathrm{S}$ & & $145^{\circ} 25^{\prime} \mathrm{E}$ & $40^{\circ} 23^{\prime} \mathrm{S}$ & $145^{\circ} 20^{\prime} \mathrm{E}$ & 45 \\
\hline 3 & $\mathrm{C} 12$ & -04 & $39^{\circ} 55^{\prime} \mathrm{S}$ & & $144^{\circ} 52^{\prime \prime} \mathrm{E}$ & $39^{\circ} 53^{\prime} \mathrm{S}$ & $145^{\circ} 00^{\prime} \mathrm{E}$ & 46 \\
\hline 4 & $\mathrm{C} 12$ & -03 & $39^{\circ} 59^{\prime} \mathrm{S}$ & & $145^{\circ} 03^{\prime} \mathrm{E}$ & $39^{\circ} 57^{\prime} \mathrm{S}$ & $144^{\circ} 59^{\prime} \mathrm{E}$ & 49 \\
\hline 5 & $\mathrm{C} 12$ & -01 & $40^{\circ} 04^{\prime} \mathrm{S}$ & & $145^{\circ} 07^{\prime} \mathrm{E}$ & $40^{\circ} 06^{\prime} \mathrm{s}$ & $145^{\circ} 09^{\prime} \mathrm{E}$ & 51 \\
\hline 6 & $\mathrm{C} 12$ & -02 & $39^{\circ} 59^{\prime} \mathrm{S}$ & & $145^{\circ} 08^{\prime} \mathrm{E}$ & $39^{\circ} 59^{\prime} \mathrm{S}$ & $145^{\circ} 07^{\prime} \mathrm{E}$ & 51 \\
\hline 7 & $\mathrm{C} 07$ & -01 & $42^{\circ} 09^{\prime} \mathrm{S}$ & & $145^{\circ} 08^{\prime} \mathrm{E}$ & $42^{\circ} 08^{\prime} \mathrm{S}$ & $145^{\circ} 05^{\prime} \mathrm{E}$ & 64 \\
\hline 8 & $\mathrm{C} 07$ & -09 & $41^{\circ} 56^{\prime} \mathrm{S}$ & & $145^{\circ} 00^{\prime} \mathrm{E}$ & $42^{\circ} 00^{\prime} \mathrm{S}$ & $145^{\circ} 02^{\prime} \mathrm{E}$ & 70 \\
\hline 9 & C11 & -01 & $40^{\circ} 47^{\prime} \mathrm{S}$ & & $144^{\circ} 16^{\prime} \mathrm{E}$ & $40^{\circ} 42^{\prime} \mathrm{S}$ & $144^{\circ} 15^{\prime} \mathrm{E}$ & $90-93$ \\
\hline 10 & $\mathrm{C} 06$ & -03 & $43^{\circ} 18^{\prime} \mathrm{S}$ & & $145^{\circ} 33^{\prime} \mathrm{E}$ & $43^{\circ} 15^{\prime} \mathrm{S}$ & $145^{\circ} 31^{\prime} \mathrm{E}$ & $157-159$ \\
\hline 11 & C06 & -01 & $43^{\circ} 18^{\prime} \mathrm{S}$ & & $135^{\circ} 32^{\prime} \mathrm{E}$ & $43^{\circ} 15^{\prime} \mathrm{S}$ & $145^{\circ} 26^{\prime} \mathrm{E}$ & 159 \\
\hline 12 & C06 & -02 & $43^{\circ} 15^{\prime} \mathrm{s}$ & & $145^{\circ} 26^{\prime} E$ & $43^{\circ} 20^{\prime} \mathrm{s}$ & $145^{\circ} 31^{\prime} \mathrm{E}$ & 159 \\
\hline 13 & C06 & -04 & $43^{\circ} 14^{\prime} \mathrm{S}$ & & $145^{\circ} 26^{\prime} \mathrm{E}$ & $43^{\circ} 17^{\prime} \mathrm{s}$ & $145^{\circ} 32^{\prime} \mathrm{E}$ & $159-163$ \\
\hline 14 & $\mathrm{CO} 4$ & -02 & $44^{\circ} 03^{\prime} \mathrm{S}$ & & $146^{\circ} 55^{\prime} \mathrm{E}$ & $41^{\circ} 01^{\prime} \mathrm{S}$ & $147^{\circ} 07^{\prime} \mathrm{E}$ & 165 \\
\hline 15 & $\mathrm{CO9}$ & -05 & $40^{\circ} 57^{\prime} \mathrm{S}$ & & $143^{\circ} 49^{\prime} \mathrm{E}$ & $40^{\circ} 58^{\prime} \mathrm{S}$ & $143^{\circ} 54^{\prime} \mathrm{E}$ & 183 \\
\hline 16 & $\mathrm{CO9}$ & -06 & $40^{\circ} 50: \mathrm{S}$ & & $143^{\circ} 53^{\prime} \mathrm{E}$ & $40^{\circ} 53^{\prime} \mathrm{S}$ & $143^{\circ} 47^{\prime} E$ & 183 \\
\hline 17 & C11 & -02 & $40^{\circ} 46^{\prime} \mathrm{S}$ & & $143^{\circ} 42^{\prime} \mathrm{E}$ & - & - & $183-220$ \\
\hline 18 & $\mathrm{CO} 4$ & -01 & $44^{\circ} 03^{\prime} \mathrm{S}$ & & $146^{\circ} 53^{\prime} \mathrm{E}$ & & $\vec{b}$ & $238-265$ \\
\hline 19 & $\mathrm{C} 07$ & -03 & $42^{\circ} 06^{\prime} \mathrm{S}$ & & $144^{\circ} 43^{\prime} \mathrm{E}$ & $42^{\circ} 00^{\prime} \mathrm{S}$ & $144^{\circ} 40^{\prime} \mathrm{E}$ & $366-420$ \\
\hline 20 & $\mathrm{C} 07$ & -07 & $42^{\circ} 05^{\prime} \mathrm{S}$ & & $144^{\circ} 41^{\prime} \mathrm{E}$ & $42^{\circ} 07^{\prime} \mathrm{s}$ & $144^{\circ} 41^{\prime} \mathrm{E}$ & $455-457$ \\
\hline 21 & $\mathrm{C} 07$ & -08 & $42^{\circ} 07^{\prime} \mathrm{S}$ & & $144^{\circ} 41^{\prime} \mathrm{E}$ & $42^{\circ} 08^{\prime} \mathrm{S}$ & $144^{\circ} 43^{\prime} \mathrm{E}$ & 457 \\
\hline 22 & $\mathrm{C} 09$ & -02 & $41^{\circ} 14^{\prime} \mathrm{s}$ & & $144^{\circ} 08^{\prime} \mathrm{E}$ & $41^{\circ} 17^{\prime} \mathrm{s}$ & $144^{\circ} 12^{\prime} \mathrm{E}$ & $457-494$ \\
\hline 23 & $\mathrm{CO} 7$ & -06 & $42^{\circ} 08^{\prime} \mathrm{S}$ & & $144^{\circ} 41^{\prime} \mathrm{E}$ & $42^{\circ} 03^{\prime} \mathrm{S}$ & $144^{\circ} 39^{\prime} \mathrm{E}$ & $485-547$ \\
\hline 24 & $\mathrm{CO9}$ & -04 & $41^{\circ} 01^{\prime} \mathrm{S}$ & & $143^{\circ} 51^{\prime} \mathrm{E}$ & $40^{\circ} 54^{\prime} \mathrm{S}$ & $143^{\circ} 44^{\prime} \mathrm{E}$ & 494 \\
\hline 25 & $\mathrm{CO} 7$ & -05 & $42^{\circ} 12^{\prime} \mathrm{S}$ & & $144^{\circ} 43^{\prime} \mathrm{E}$ & $42^{\circ} 08^{\prime} \mathrm{S}$ & $144^{\circ} 40^{\prime} \mathrm{E}$ & $530-567$ \\
\hline 26 & $\mathrm{CO} 2$ & -01 & $40^{\circ} 48^{\prime} \mathrm{S}$ & & $143^{\circ} 36^{\prime} \mathrm{E}$ & $40^{\circ} 41^{\prime} \mathrm{S}$ & $143^{\circ} 31^{\prime} \mathrm{E}$ & 550 \\
\hline 27 & $\mathrm{CO3}$ & -01 & $42^{\circ} 20^{\prime} \mathrm{S}$ & & $144^{\circ} 47^{\prime} \mathrm{E}$ & & 0 & 550 \\
\hline 28 & $\mathrm{CO9}$ & -01 & $41^{\circ} 19^{\prime} \mathrm{s}$ & & $144^{\circ} 11^{\prime} \mathrm{E}$ & $41^{\circ} 14^{\prime} \mathrm{S}$ & $144^{\circ} 05^{\prime} \mathrm{E}$ & 550 \\
\hline 29 & $\mathrm{C} 11$ & -04 & $40^{\circ} 43^{\prime} \mathrm{S}$ & & $143^{\circ} 33^{\prime} \mathrm{E}$ & $40^{\circ} 47^{\prime} \mathrm{S}$ & $143^{\circ} 36^{\prime} \mathrm{E}$ & 550 \\
\hline 30 & C15 & -01 & $40^{\circ} 32 \cdot \mathrm{S}$ & & $143^{\circ} 27^{\prime} \mathrm{E}$ & $40^{\circ} 39^{\prime} \mathrm{S}$ & $143^{\circ} 30^{\prime} \mathrm{E}$ & 550 \\
\hline 31 & C15 & -02 & $40^{\circ} 55^{\prime} \mathrm{S}$ & & $143^{\circ} 55^{\prime} \mathrm{E}$ & - & - & 550 \\
\hline 32 & C15 & -03 & $41^{\circ} 05^{\prime} \mathrm{S}$ & & $143^{\circ} 54^{\prime} \mathrm{E}$ & & 0 & 550 \\
\hline 33 & $\mathrm{C} 17$ & -01 & $41^{\circ} 33^{\prime} \mathrm{S}$ & & $148^{\circ} 38^{\prime} \mathrm{E}$ & $41^{\circ} 36^{\prime} \mathrm{S}$ & $148^{\circ} 38^{\prime} \mathrm{E}$ & 550 \\
\hline 34 & C1. 7 & -02 & $42^{\circ} 23^{\prime} \mathrm{s}$ & & $148^{\circ} 33^{\prime} \mathrm{E}$ & $42^{\circ} 17^{\prime} \mathrm{s}$ & $148^{\circ} 39^{\prime} \mathrm{E}$ & 550 \\
\hline 35 & $\operatorname{Cog}$ & -03 & $41^{\circ} 10^{\prime} \mathrm{S}$ & & $144^{\circ} 01^{\prime} \mathrm{E}$ & $41^{\circ} 02^{\prime} \mathrm{S}$ & $143^{\circ} 52^{\prime} \mathrm{E}$ & $530-640$ \\
\hline 36 & $\mathrm{C} 06$ & -05 & $42^{\circ} 14^{\prime} \mathrm{S}$ & & $144^{\circ} 43^{\prime} \mathrm{E}$ & $42^{\circ} 21^{\prime} \mathrm{S}$ & $144^{\circ} 47^{\prime} \mathrm{E}$ & $622-658$ \\
\hline 37 & $\mathrm{C} 08$ & -03 & $41^{\circ} 20^{\prime} \mathrm{S}$ & & $144^{\circ} 12^{\prime} \mathrm{E}$ & $41^{\circ} 15^{\prime} \mathrm{S}$ & $144^{\circ} 03^{\prime} \mathrm{E}$ & $622-722$ \\
\hline 38 & $\mathrm{C} 08$ & -02 & $42^{\circ} 15^{\prime} \mathrm{S}$ & & $144^{\circ} 43^{\prime} \mathrm{E}$ & $42^{\circ} 19^{\prime} \mathrm{s}$ & $144^{\circ} 46^{\prime} \mathrm{E}$ & $680-710$ \\
\hline 39 & $\mathrm{C} 11$ & -03 & $40^{\circ} 40^{\prime} \mathrm{S}$ & & $143^{\circ} 29^{\prime} \mathrm{E}$ & & & $677-750$ \\
\hline 40 & $\mathrm{C} 08$ & -01 & $42^{\circ} 21^{\prime} \mathrm{S}$ & & $144^{\circ} 45^{\prime} \mathrm{E}$ & $42^{\circ} 15^{\prime} \mathrm{S}$ & $144^{\circ} 43^{\prime} \mathrm{E}$ & 732 \\
\hline
\end{tabular}


Depth (m)

$<27$

$27-91$

$91-275$

$275-457$

$457-640$

$>640$

SPECIES

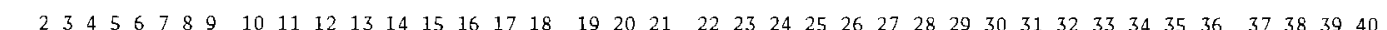
HETERODONTIDAE

Heterodontus portusjacksoni

HEXANCHIDAE

even-gilled shark
votorhynchus cer

hynchus cereaianus

OREC TOLOBIDAE

rusty catshark
Parascyllium fermugineum

SCYLIORHINIDAE

draughtboard shark
Cephaloscylzium laticep.

spotted catshark

Asumbolis anazis

Galeus boardrani

ARCHARHINIDAE

guniny shark
Mhstelus ontareticus

school shark

SQUALIDAE

prickly dogfish

Oxynotus bmuniensis
ong snouted dogfish

Deania quadriaspinos

brier shark

Deania calcea

Centropho

lord Plunket's shark

Scymnodon plunketi
Mollers deepsea shark

Etmop terus lucifer

Squalus megalops

green-eyed dogfish

squalus brainvillei

White-spot ted thiag

Squalus acant
golden dogfish

Centroscymrus crepicator

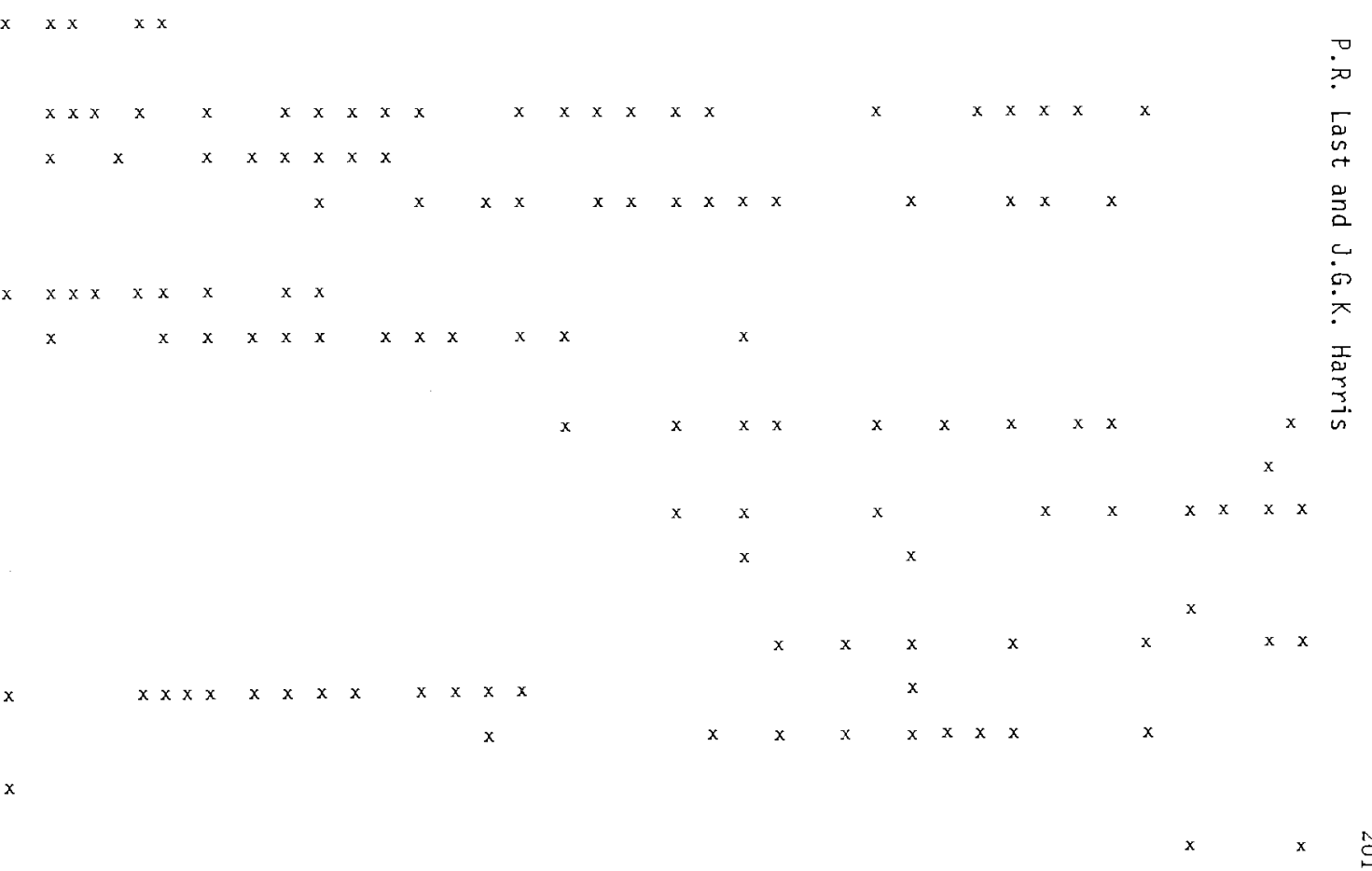




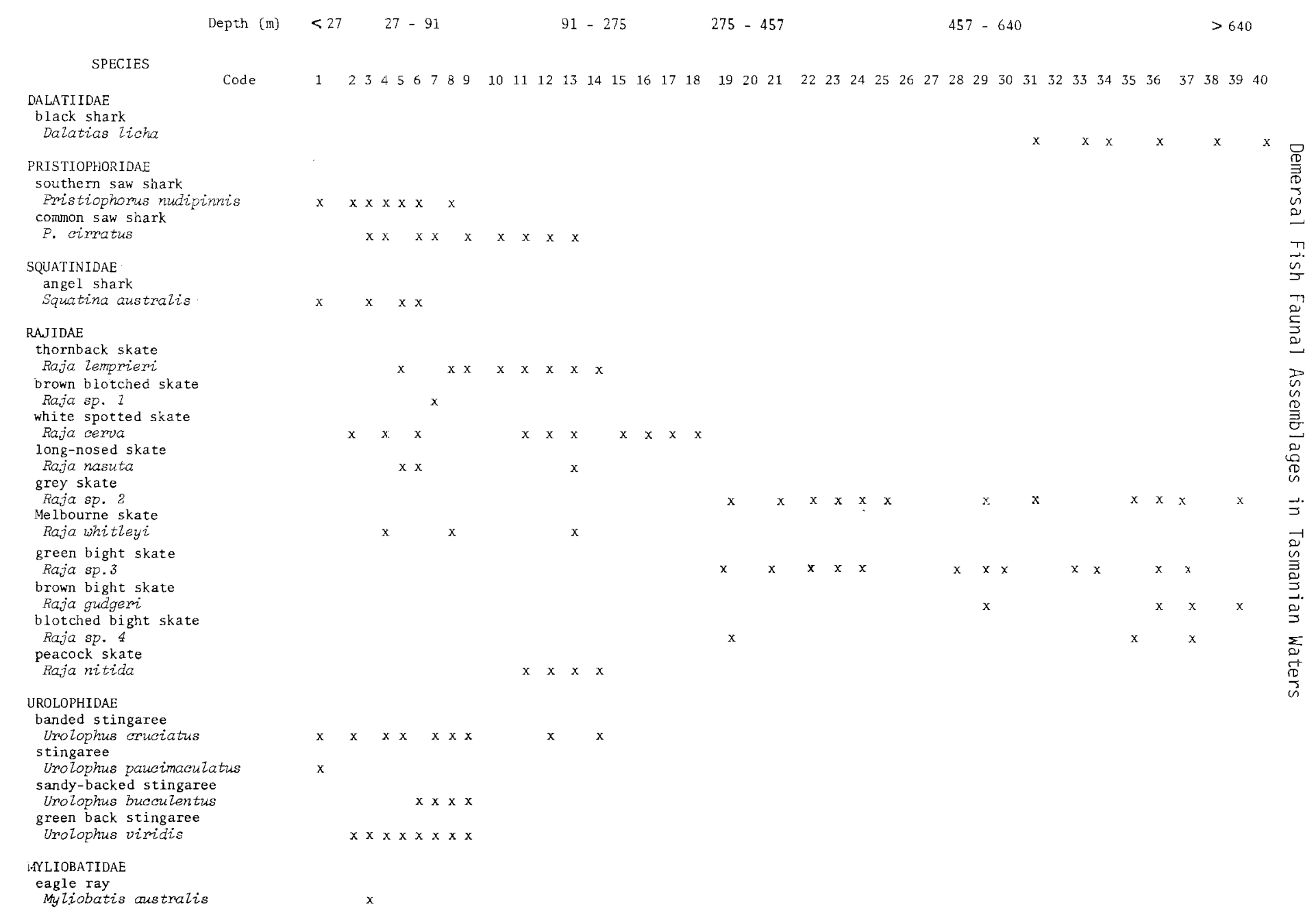



Depth $(\mathrm{m}) \quad<27 \quad 27-91$
$91-275$
$275-457$
$457-640$

$>640$

SPECIES

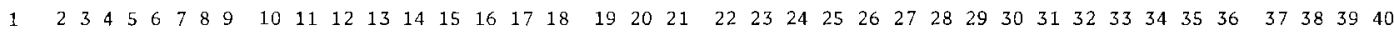

TORPEDINIDAE

torpedo ray tasmaniensis

electric ray
Torpedo macneiziz

RHINOBATIDAE

Trygonorhina fasciata

CALLORHYNCHIDAE

elephant fish
Callorhynchus milii

CHIMAERIDAE

Ogilby's ghost shark

Hydrolagus ogit
ghost shark

Hydrolagus sp.

RHINOCHIMAERI DAE

spookfish
Harmiotta raleighana

CONGRIDAE

little conger eel

deepsea conger eel

Fseudoxenomys tax hinipsutus

ARGENTINIDAE

Sllverside

ChLOROPTHALNidDaE

cucumber fish

NEOSCOPELIDAE

large-scaled lantern fish

Meoseopelus macrolepidotus

MORIDAE

red cod

deep sea cod. 

Depth $(m)<27$
$27-91$
$91-275$
$275-457$
$457-640$
$>640$

SPECIES

Code

Tasmanian cod

Physicutus marginatus

Fhysiculus marginatus
Eucla cod
Euclichthys poinnemus

Euctichthys polynemus

grenadier cod

OPHIDI IDAE

rock ling

MACROURIDAE

southern whiptail

Coelorinchus aus trazis

banded whiptail
Coelorinchus fasciatu

Celorinchus fasciatu
large headed whiptail

Coelorinchus matam

innotable whiptail
Coelorinchus innotabizis

toothed whiptail

Lepidorhynchus àent

Ventrifossa nigromaculata

MERLUCCIIDAE

blue grenadier
Maeruronus novaezelanäiae

TRACHICHTHY IDAE

New Zealand sawbe $11 y$

Hoplosicthus intermedius

sandpaper fish
Faratrachichthys traitu

BERYCIDAE

alfonsin

EIDAE

cyttus travers

silver dory

Cyttus australis

zenopsis nebutosu

John dory
Zeus faber

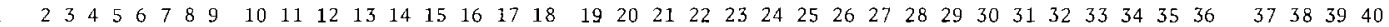
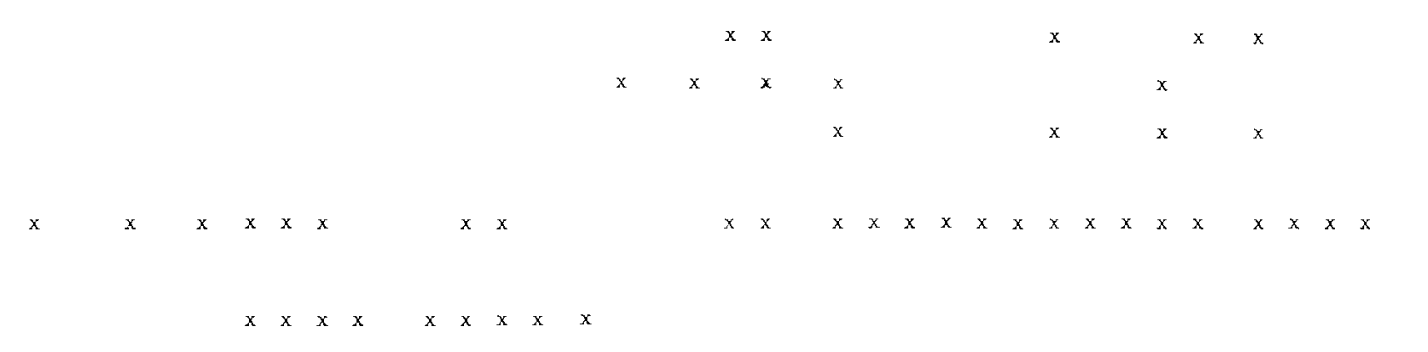

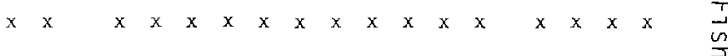

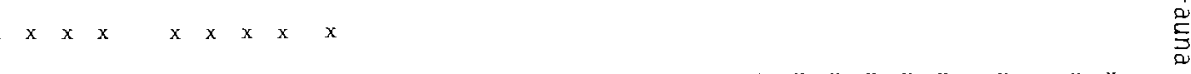

$\begin{array}{llllllllllllllllllllllll}x & x & x & x & x & x & x & x & x & x & x & x & x & x & x & x & x & x & & x & x & \\ x & & & & & & x & & & x & & & & & & x & & x & x & x & \end{array}$
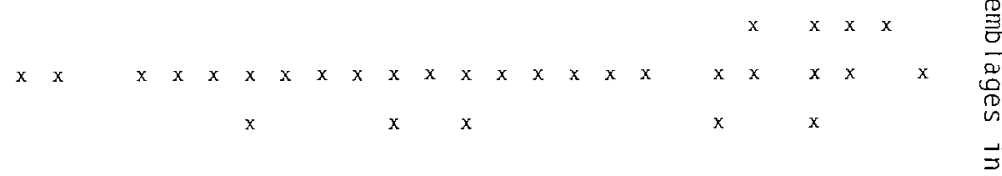

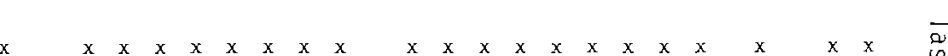

$\stackrel{-1}{g}$ 

Depth (m)
$27-91$
$91-275$
$275-457$
$457-640$
$>640$

SPECIES

Code

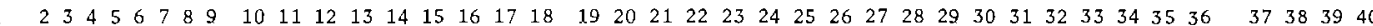
New Zeal and dory
Cyttus novaezelandias

OREOSOMATIDAE

Spiky dory

ox-eyed dory
Cyttosoma boops

MACRORHAMPHOSIDAE

Centriscops ow fish

centriscops obliquus

Macrorhanphosus scolopax

rested bellows fish

Notopogon lizlei

$x \quad x \quad x$

SCORPAENIDAE

red gurnard perch
Helicolenus papizlosus

thetis fish

Neosebastes thetidi

Common gurnard perch
Neosebastes scompaenoides

Meosebastes scorpaenoides
goblin fish
Glyptauchen panduratus

\section{TRIGLIDAE}

red qumard

ichthys keme

Pterygotrigla polyommata

butterfy gurnard

round snouted gurnard

Lepidotrigla mulhalli

grooved gurnard

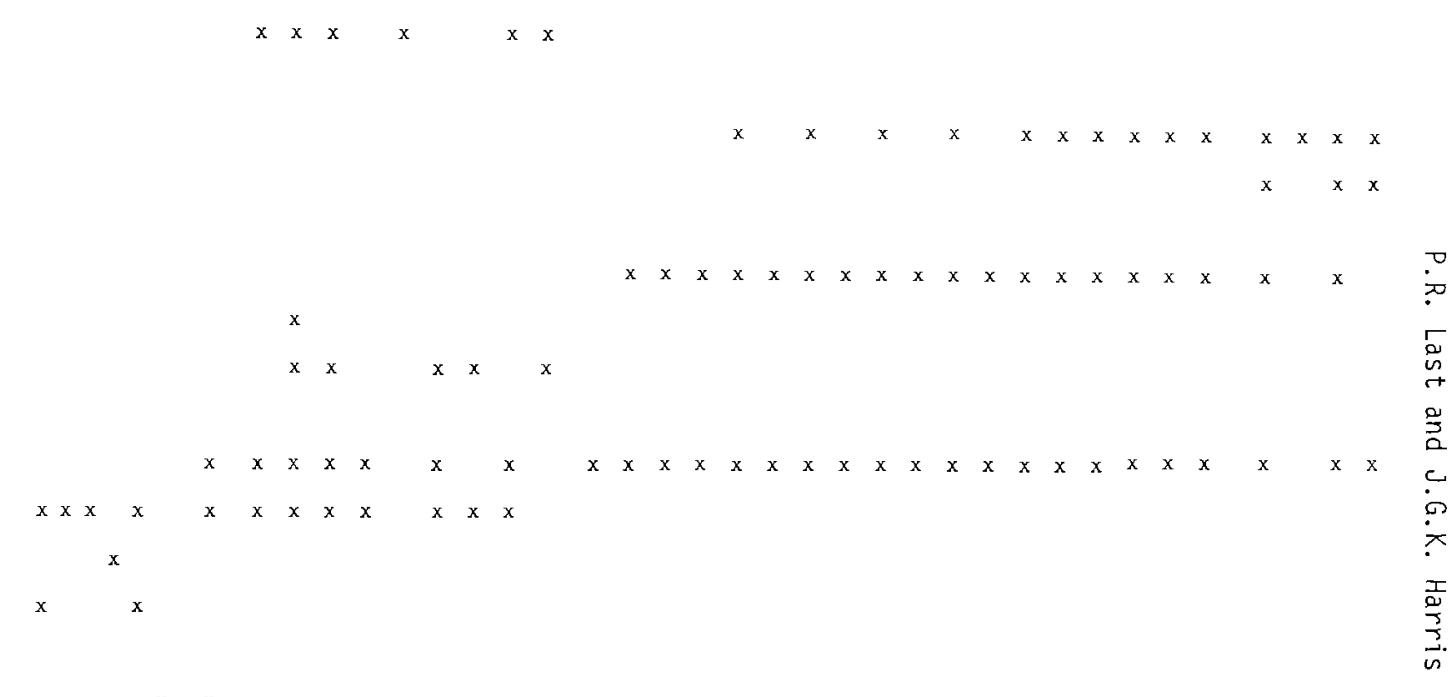

PLATYCEPHALIDAE

tiger flathead
Platycephalus richardsoni

deep-water flathead

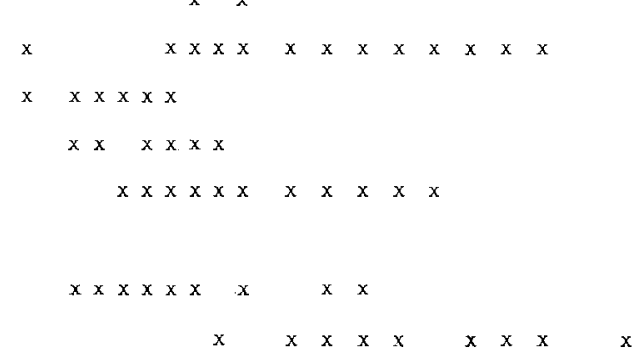



Depth
$27-91$
$91-275$
$275-457$
$457-640$

$>640$

SPECIES

$1223456789101112131415161718 \quad 192021 \quad 222324 \quad 252627282930 \quad 3132 \quad 333435 \quad 36 \quad 3738 \quad 3940$

toothed whiptail
Lepidorhynchus denticulatus

Lepidorhynchus ail

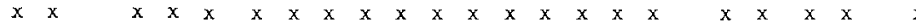

Ventrifossa nigromaculata

and thathead

HOPLICHTHYIDAE

Hoplichthys haswe 2 .

PSYCHROLUTIDAE

Neophrynichthys marcidus

CALLIONYMIDAE

Comlizonymas calcurropormus

long spined stinkfish

callionymis phasis

SERRAN I DAE

rosy perch
Callanthias alzporti

orange perch
Anthias putcheizus

hapuku

CARANGIDAE

jack mackere 1

ME LICHTHY IDAE

redbait

APOGONIDAE

big-eye cardinal fish

Epigonus lenimen

white cardinal fish
Epigonus denticulat

GERREIDAE

Silverbelly
Farequila me ibourmensis

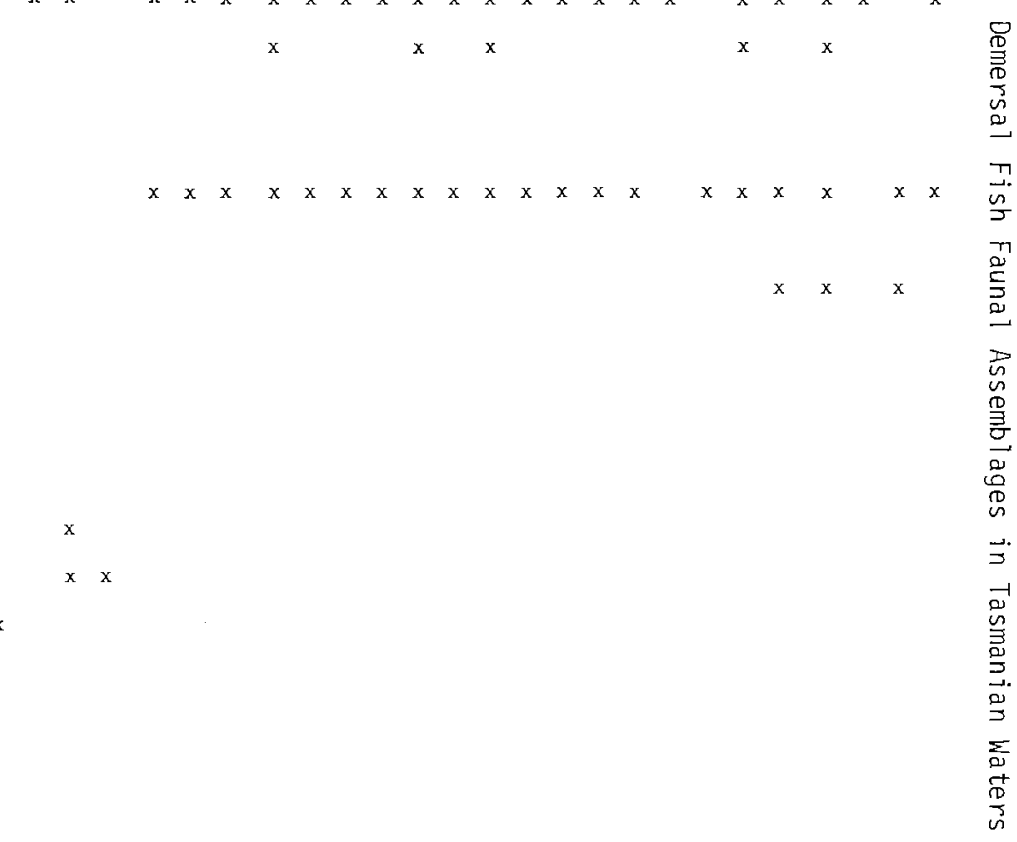



Depth (m) $\quad<27$
$27-91$
$91-275$
$275-457$
$457-640$
$>640$

SPECIES

gemfish
Rexea solandri

CENTROLOPHIDAE

deep sea trevalla

Hyperoglyphe antaretica

Seriolella punctat

white trevalla
Seriolella saemilea

PLEURONECTIDAE

long-snouted flounder

Amotretis rostratus

spotted flounded

Ammotretis liturata

Phombosolea tapi

BOTHI DAE

Andrew's flounde

Armoglossus condrewsi

TE TRAODONTIDAE

ringed toadfish
Arothron armizla

OSTRACIONTIDAE

Shaws cowfish

MONACANTHIDAE

cosmopolitan leatherjacket

Degen's leatherjacket

Thamnaconus degeni

mosaic leatherjacket
Eubatichthys mosaicus

DIODONTIDAE

porcupine fish

Porcupine fish

globe fish

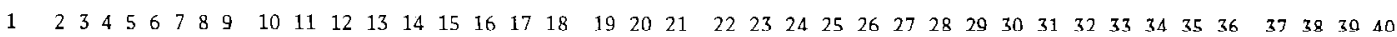

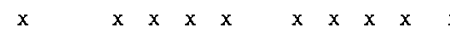

$x \times x \times$

$\begin{array}{llllllllllll}x & x & x & x & x & x & x & x\end{array}$

$x \times$

$x \quad x \quad x \quad x \quad x$
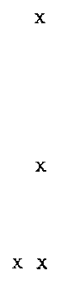

$\mathrm{x} \times \mathrm{x} \times \mathrm{x}$

$\mathrm{x} \times \mathrm{x}$

$x$

$x$

$x \quad x \quad x$

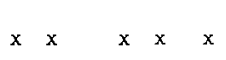



Depth $(\mathrm{m}) \quad<27 \quad 27-91$
$91-275$
$275-457$
$457-640$
$>640$

SPECIES

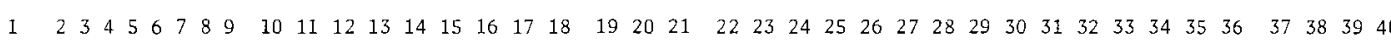
SPARIDAE

snapper

MULLLIDAE

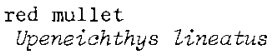

Upereichthys

giant boarfish

Paristiopterus tabiosus

black-spotted boarfish

pelagic armourhead

Pentaceros richorás

Peng-snouted boarfish
Pentaceropsis recurvirostri

OPLEGNATHIDAE

Knife jaw

CAEI IODACTYLIDAE

morwong
Nemadacty lus macropterus

PARAPERCIDAE

barred grubfish
Parapercis allporti

$x$

CREEDIDAE

Haswells sandfish
Creedia haswelli

URANASCOPIDAE

bulldog stargazex
Gnathagnus innotabli

barred stargazer

speckled stargazer

Kathetostoma gigonteum

scaled stargazer

Pleuroscopus sp.

GEMPYLIDAE

Snoek Thyrsites atuon

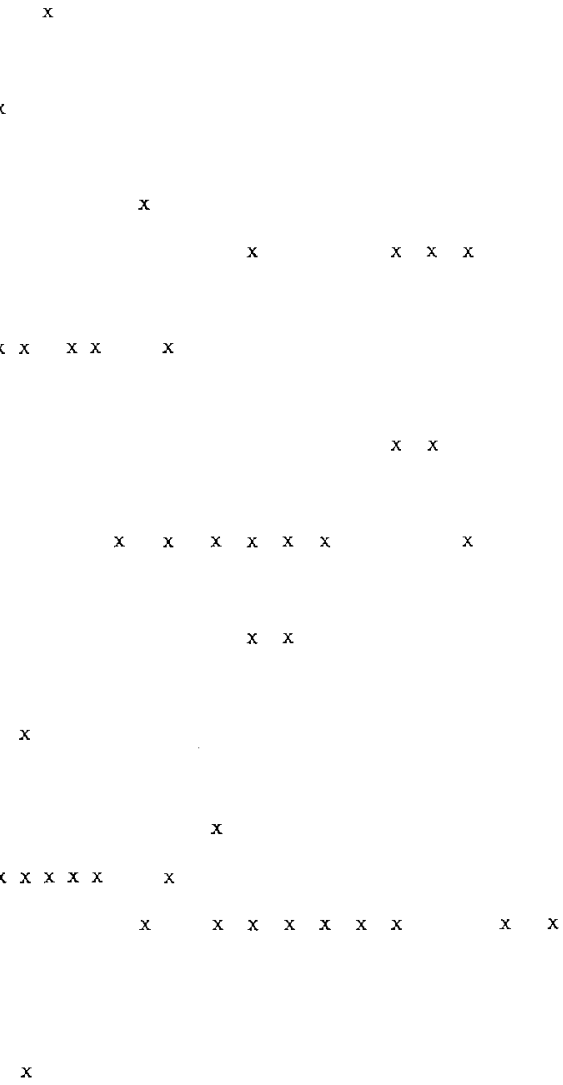


P.R. Last and J.G.K. Harris

APPENDIX 3

RELATIVE ABUNDANCE BY WEIGHT FOR EACH DEPTH RANGE (METRES) OF THE TEM MAJOR SPECIES GIVING THEIR PERCENTAGE CONTRIBUTION (p) TO THE TOTAL CATCH WEIGHT (w) AT THAT DEPTH FROM n SAMPLES. TOTAL $\left(C_{T}\right)$ AND COMMERCIAL $\left(C_{c}\right)$ CATCH RATES ARE ALSO GIVEN.
1. $\quad 0-29$ metres
$\%$ weights
2. 27-91 metres
$\%$ weights

$\begin{array}{lr}\text { Elephant fish } & 33.5 \\ \text { Sand Flathead } & 12.9 \\ \text { Banded Stingaree } & 8.4 \\ \text { Bearded Rock Cod } & 8.4 \\ \text { Butterfly Gurnard } & 8.4 \\ \text { Latchet } & 8.4 \\ \text { Spiked Dogfish } & 4.5 \\ \text { Southern Sawshark } & 4.5 \\ \text { Rusty Catshark } & 2.2 \\ \text { Gummy Shark } & 2.2 \\ \text { p }=93.4 \% & \\ \text { w }=179 \mathrm{~kg} \quad \mathrm{C}_{\mathrm{T}}=119.4 \mathrm{~kg} / \mathrm{hr} \\ \mathrm{n}=1 & \mathrm{C}_{\mathrm{C}}=67.9 \mathrm{~kg} / \mathrm{hr}\end{array}$

3. 91-275 metres

$\%$ weights

$\begin{array}{lr}\text { Jackass Fish } & 22.1 \\ \text { Latchet } & 12.5 \\ \text { Porcupine Fish } & 7.7 \\ \text { Cucumber Fish } & 6.7 \\ \text { School Shark } & 6.3 \\ \text { Speckled Stargazer } & 5.1 \\ \text { Ogilby's Ghost Shark } & 5.0 \\ \text { Spiked Dogfish } & 4.5 \\ \text { Denticulated Skate } & 3.8 \\ \text { Southern Calamary } & 2.9 \\ \mathrm{p}=76.6 \% & \\ \mathrm{w}=4826 \mathrm{~kg} \quad \mathrm{C}_{\mathrm{T}}=181.9 \mathrm{~kg} / \mathrm{hr} \\ \mathrm{n}=9 & \mathrm{C}_{\mathrm{C}}=104.19 \mathrm{~kg} / \mathrm{hr}\end{array}$

\section{5. $\quad 457-640$ metres}

$\%$ weights

King Dory

Toothed Whiptail $\quad 18.2$

Blue Grenadier

Red Gurnard Perch 9.7

Banded Bellows Fish 4.5

Spiky Dory 2.8

Deepwater Ghost Shark $\quad 1.8$

Gemfish 1.7

Deep Sea Cod 1.5

Rockling

$\mathrm{p}=92.6 \%$

$\mathbf{w}=24760 \mathrm{~kg} \quad \mathrm{C}_{\mathrm{T}}=342.32 \mathrm{~kg} / \mathrm{hr}$

$\mathrm{n}=15 \quad \mathrm{C}_{\mathrm{c}}=243.6 \mathrm{~kg} / \mathrm{hr}$
4. 275-457 metres

$\%$ weights

$\begin{array}{lr}\text { Green Back Stingaree } & 32.1 \\ \text { Bearded Rock Cod } & 24.5 \\ \text { Rounded Snouted Gurnard } & 8.3 \\ \text { Latchet } & 3.6 \\ \text { Banded Stingaree } & 3.4 \\ \text { Thetis Fish } & 3.2 \\ \text { Gummy Shark } & 1.9 \\ \text { Ange1 Shark } & 1.8 \\ \text { Arrow Squid } & 1.6 \\ \text { Elephant Fish } & 1.6 \\ \text { p }=82.0 & \\ \text { w }=3359 \quad C_{T}=207.6 \mathrm{~kg} / \mathrm{hr} \\ \mathrm{n}=8 \quad \mathrm{C}_{\mathrm{C}}=84.45 \mathrm{~kg} / \mathrm{hr}\end{array}$

Toothed Whiptail 65.8

Blue Grenadier $\quad 14.2$

Mirror Dory $\quad 7.5$

Green Bight Skate 2.5

Banded Whiptail 2.1

Deepwater Ghost. Shark 1.3

School Shark 1.3

Draughtboard Shark 1.1

Red Gurnard Perch 1.1

Spiny Flathead $\quad 1.1$

$\mathrm{p}=98.0 \%$

$\mathrm{w}=1800 \mathrm{~kg} \quad \mathrm{CT}=502.3 \mathrm{~kg} / \mathrm{hr}$

$\mathrm{n}=3 \quad \mathrm{C}_{\mathrm{c}}=129.2 \mathrm{~kg} / \mathrm{hr}$

6. Greater than 640 metres $\%$ weights

$\begin{array}{lr}\text { Spiky Dory } & 58.3 \\ \text { Toothed Whiptail } & 11.3 \\ \text { Deep Sea Cod } & 3.6 \\ \text { King Dory } & 3.3 \\ \text { Red Gurnard Perch } & 2.9 \\ \text { Banded Bellows Fish } & 2.7 \\ \text { Southern Whiptail } & 2.7 \\ \text { Brier Shark } & 2.5 \\ \text { Rockling } & 2.4 \\ \text { Deepwater Ghost Shark } & 1.9 \\ \text { p }=91.6^{\circ} & \\ \text { w }=5646 \mathrm{~kg} \quad \mathrm{C}_{\mathrm{T}}=442.8 \mathrm{~kg} / \mathrm{hr} \\ \mathrm{n}=4 & \mathrm{C}_{\mathrm{C}}=333.7 \mathrm{~kg} / \mathrm{hr}\end{array}$

